\title{
UDC 004.02:005
}

\section{DOI: 10.31866/2617-796x.3.1.2020.206096}

\section{Tkachenko Olha,}

PhD in Phisics and Mathematics,

Associate Pprofessor at the department of Information Technologies,

State University of Infrastructure and Technology,

Kyiv, Ukraine

oitkachen@gmail.com

https://orcid.org/0000-0003-1800-618X

\section{Tkachenko Oleksandr,}

PhD in Phisics and Mathematics,

Associate Pprofessor at the department of Information Technologies,

National Aviation University,

Kyiv, Ukraine

aatokg@gmail.com

https://orcid.org/0000-0001-6911-2770

\section{Tkachenko Kostiantyn,}

PhD in Economics,

senior lecturer at the department of Information Technologies,

State University of Infrastructure and Technology,

Kyiv, Ukraine

tkachenko.kostyantyn@gmail.com

https://orcid.org/0000-0003-0549-3396

\section{ONTOLOGICAL MODELING OF SITUATIONAL MANAGEMENT}

The purpose of the article is to research and consider general problems and perspectives of modeling of situational management in particular ontological modeling.

The research methods cosist of the methods of semantic analysis of the basic concepts of the considered subject area (situational management). The article considers approaches to the development of appropriate ontological models.

The novelty of the research is the analysis of ontologies and their application to modeling of processes of situational management.

The conclusion of the research conducted in the article is as follows: analyzes the similarities of the structural diagram of the decision-making process for regulating the problem situation and the general scheme of ontological modeling. Between the elements of these schemes, compliance is established to justify the ontological approach to the implementation of situational management.

The contents of the corresponding elements of the schemes are compared with the aim of revealing the mechanisms of situational management. The construction of information models

(C) Ткаченко О.І.

(C) Ткаченко О. А.

(C) Ткаченко К. А 
of understanding in situational management is proposed to be considered as the task of constructing ontologies of subject areas and ontological models of situations.

Keywords: subject area; system models, ontology; ontology model; situational management; decision-making process; regulating the problem situation.

Introduction. Information is one of the most important resources of the modern world. Situational management of processes that occur in society, production, education and science is an important aspect of their functioning. To date, a huge amount of information has been accumulated, which is not used to the full in the organization of management, including situational. To solve these problems, ontological modeling is used.

The main objective of ontological modeling in situational management is the construction of adequate ontologies and ontological models of situations.

Many authors have studied various aspects of modeling processes and systems in these areas of human activity (Kulinich, 2003; Maksimov, Kornoushenko and Kachaev, 1999; Kostenko, 2016; Denisenko and Krasina, 2014). The authors of these works, in particular, argue that the simulation has an iterative nature, when each stage includes an analysis of the result obtained and it is possible to return the process to any of the preceding stages.

The main text of the article. Conceptual models of subject areas (SA) can be naturally identified with ontologies. Figure 1 shows the scheme of ontological modeling of the SA. Here OM is the object model of the $i$-th subdomain of $S A(i=1, \ldots, M), T_{j}$ is the transformation model of $\mathrm{SA}(\mathrm{j}=1, \ldots, \mathrm{K})$.

The scheme is presented without feedbacks, which allows us to understand only the sequence of stages of the simulation of software.

Information necessary for situation management can be provided in the form of multimedia, texts, data bases, etc. The type, type, and degree of accessibility of source information affects the ontological modeling.

Difficulties can arise in the semantic analysis of texts in natural languages. It is better to deal with structured reference data, for example, measurement protocols in the form of "object-property" tables (https://spravochnick.ru/informatika), relational data bases (https://younglinux.info/sqlite/db), etc.

The incompleteness of the information can be taken into account in ontological models and/or investigated by various methods of data analysis (Rubakov, 2008).

Providing in-source information in a form convenient for situational management is the task of ontological modeling. We are talking about the aggregation of being in a formal way, suitable for constructive theoretical analysis.

The problem of ontological modeling can be reformulated as follows: providing the source information in a convenient form should be understood as the task of creating subject-oriented interfaces to disparate sources of information about actual, objective information.

Awareness of the problem situation and the formation of adequate structures for its regulation (overcoming) contain the nature of the organization of complex system (Tkachenko, ed., 2019; Greger and Porshnev, 2013; http://www.ipu.ru/labs/lab51/ projects.htm; Smirnov, 2001). 


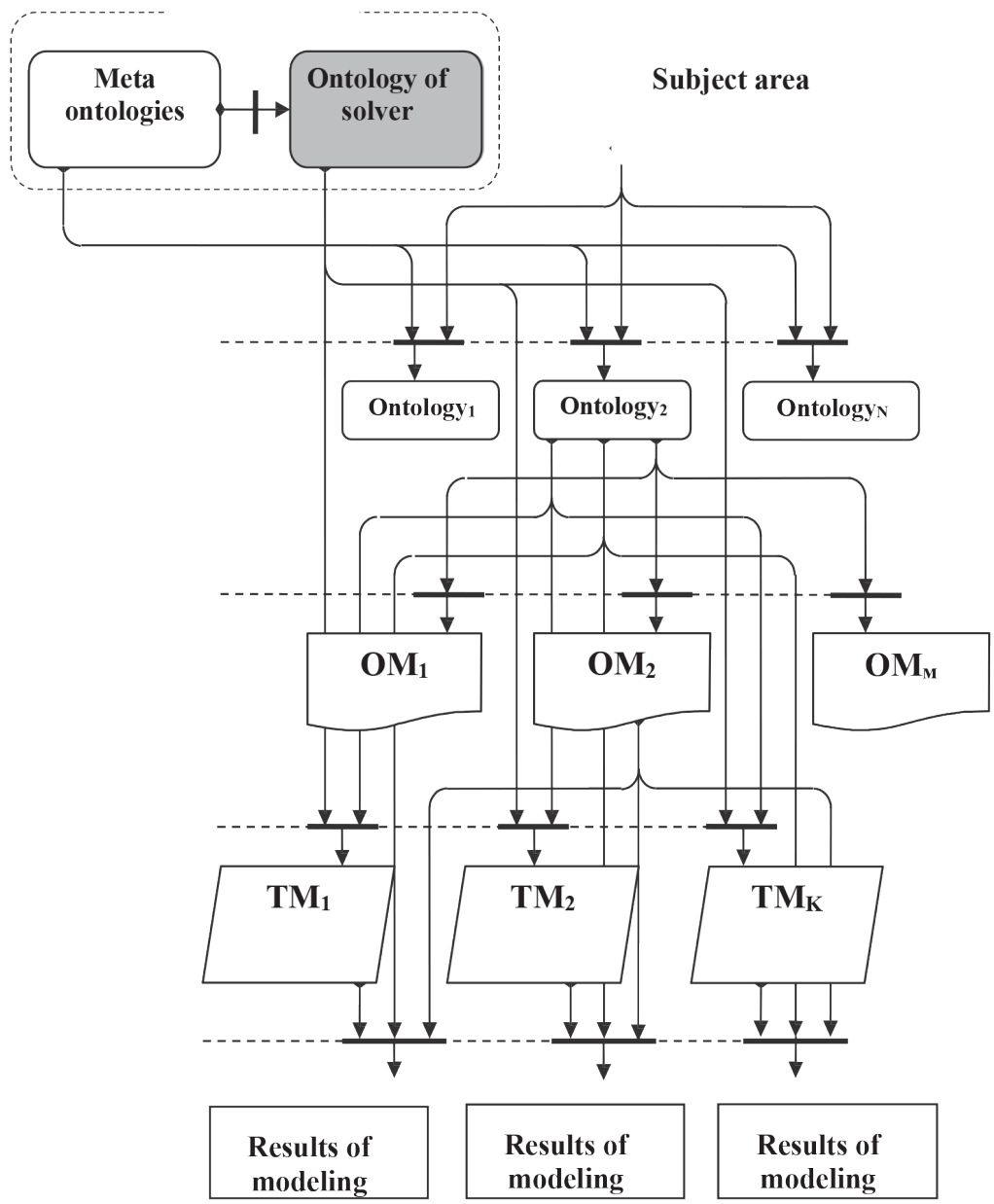

Fig. 1. Scheme of ontological modeling (top-down)

Identification of problem situations can be based on knowledge engineering: various models based on visualization of network structures (intelligence cards, conceptual graphs, Isikawa diagrams, etc.); methods for extracting knowledge (from passive observation to "brainstorming" and discussion "behind a round table").

Ontological modeling provides visualization of models that stimulate cognitive abilities of users in the structuring of information, and are applicable for creating registers of problem situations (not only with a linear, but also with a network structure).

Ontological models can be integral parts of the information model of a problematic situation, determining its corresponding aspects.

Ontologies as an interface to domain information. A lot of subjects are involved in the design and management of the conceptual information technology model of the SA. Ontology is the means of their communication. 
Therefore, the stage of conceptual analysis of the ontological modeling of ontological modeling corresponds to the stage of fixing (in the form of ontology) the preferences of decision makers when making decisions on the regulation of a problem situation.

Understanding the problematic situation depends on the target settings of the subjects in the process of analysis and generalization of the data available to them and reveals the semantics of information.

The comprehended understanding filters and configures the data arriving to the subject. It is in this context that the development of ontology can be considered as the creation of an object-oriented interface to accessible sources of information about SA.

Nowadays, there are three main ways of developing an ontology.

Most often, a path is used that is associated with a direct formalization of the subject's experience and knowledge. The construction of the ontology of the SA is carried out in a language defined by the metamodel of ontological specifications, when the subject - the expert of the SA - forms his own understanding or uses the help of a knowledge engineer.

The second way is implemented by means of ontological engineering in the presence of tested ontologies of a different level and direction. In this case, the ontologies are synthesized as a result of the procedures performed by an expert of the R\&D jointly with the knowledge engineer.

The third way is connected with the automatic "deduction" of the ontology from the available data, which can be the results of measurements of objects of the simulated software.

These results are represented by the tables "property-properties", the analysis of which leads to the identification of the conceptual structure of the SA. Often the methods of this path are based on the analysis of formal concepts, adapting it to the tasks of ontological engineering.

The role of the subject in such an ontological analysis of the data (Smirnov, 2001; Bondarenko, Matorin and Soloveva, 2000) changes dramatically: nominally, he is excluded from the "actors".

Its task becomes a priori completeness of the spectrum of measurement procedures, with the help of which the software is studied. Formally, this problem corresponds to the hypothesis about the properties of SA objects.

Any manifestation of validity allows for many interpretations that correspond to interconnected understandings of a problem situation. They may contradict each other and mutually supplement one another, when each interpretation reflects only a narrow view of the SA.

This is reflected in the possibility of constructing several different ontologies simultaneously SA the first stage of ontological modeling - the stage of conceptual analysis of ontological modeling (Fig. 1).

When solving real tasks of situational management, these ontologies - ontologies of the "target" SA - are supplemented by the independently existing ontologies of other SA, which in the context of the original problem have a method-oriented, instrumental character (Bondarenko, Matorin and Soloveva, 2000). 
A complete picture of all ontologies that are involved in the decision-making process for regulating a problematic situation is given by analytical methods of ontological engineering, and the understanding of the subjects is based on methods for comparing and combining ontologies.

Ontological models of situations. At present, as a fundamental basis of ontological modeling, the most commonly used are logistic descriptors and a methodology for analyzing formal concepts.

And since the basic elements of ontological specificity are the classes, relations, functions, and axioms, such a representation is close to the algebraic systems of A.N. Maltsev, building from a similar set of modeling primitives.

Ontological models of situations are often identified with denotations of ontology - object models of SA. Indeed, the result of the denotative modeling phase is a description of the specific situation as a system of interconnected objects of SA.

The description is carried out in accordance with the understanding fixed by the ontology of this software.

The correct construction of ontological models of situations means the following:

- every object of the ontological model of the situation is in relation to instanceization with one of the fundamental (i.e., not generalizing) concepts of the ontology of the SA;

- for the properties of the object, the set of which is established by the content of the corresponding concept, the values are determined (at least partially);

- all axioms of the SA are fulfilled, which are enclosed in its ontology and are formulated in the form of restrictions for the values of the properties of objects;

- communications between objects are reflected in the values of the special reference properties of the objects.

In ontological modeling, any ontological model of the situation is exogenous, since its occurrence is caused by an external cause - understanding by the subjects of the problematic situation. However, this does not mean the unity of subjects in the assessment of the simulated situation.

The achievement of an understanding by different subjects of a problem situation is based on the joint construction of an ontological model of the situation (Tkachenko, ed., 2019; Greger and Porshnev, 2013; http://www.ipu.ru/labs/lab51/projects.htm; Smirnov, 2001), sometimes called the object model.

The ontological model of the situation is a description of the situation in the form of concepts and relationships through the dialogue of subjects. In the process of developing such a model, the knowledge of subjects united by the general idea of a problem situation is integrated.

The ontological model of the situation should be built in real time. Using this model, some integrated idea of the problem situation is created, expressing a common understanding of the situation by all actors.

A common understanding of the problem situation does not mean that there is a common understanding of ways to overcome it.

This does not mean that a solution to the problem associated with finding a way to resolve the situation was found, since it may turn out that some characteristics of the 
situation (for example, the distribution of financial resources) do not suit individual entities.

In other words, there is understanding, the task is clear to everyone, but there is no solution. Thus, understanding the situation initially leads only to the statement of the problem, and not to its solution.

The stage of understanding in the decision-making process to overcome the problem situation (regular or contingency) ends with the statement of the problem, which is expressed in the constructed ontological model of the situation.

The process of further coordination of the points of view and concessions of the subjects is iterative in nature and comes down to the transformation of the ontological model of the situation, since it reflects, but still satisfies, the conflicting demands of the subjects.

As a result of mutual coordination, a model is developed in which mutual understanding and consensus of different actors is achieved.

The preferences of the subjects depend on the context and nature of the interactions between them, and preference scales are built in the negotiation process, not being a priori given.

This limits the use of classical mathematical methods when conducting experiments with ontological models of situations, and leads to the search for other methods, which, for example, include multiagent models and technologies (Osipov; Boev).

Transformational modeling and finding solution. Ontological modeling for solving problems provides for the development of special transformational object models denotates "technological" SA, which is defined by the ontology of problem solvers (Fig. 1).

The construction of transformational models can be considered as a specification of the scenario or schedule for solving the problem, a description of the effects on the exogenous denotative model of the "target" SA, as a result of which it must acquire some satisfying subjects.

The operational basis of the transformation is the calculation, which is based on the functional components of ontologies, which are used jointly in solving the problem and describe various aspects of the "target" SA, and also other SA (if necessary).

As functional components of ontologies, properties and methods of their fundamental concepts usually come out (Kulinich, 2003; Maksimov, Kornoushenko and Kachaev, 1999; Kostenko, 2016; Denisenko and Krasina, 2014).

According to the diagram in fig. 1, after understanding the subjects, transformational models can be developed in parallel with the construction of an ontological model of the situation. At the same time, the multiplicity of transformational models reflects the many different tasks in each SA and the many ways to solve them.

At the stage of computing the situation ontological model, the scenario of solving the problem (overcoming the problematic situation), developed in the form of a transformational model, is applied.

The exogenous ontological model of the situation is transformed into endogenous - "The result of modeling" (Fig. 1). 
The degree of participation of subjects in this model provides a scenario for solving the problem, which can reflect any methods of solving the problem: struggle to defer personal and group interests, striving for interest, etc.

To regulate a problematic situation, the following is important:

- the sequence of effects on an exogenous ontological model of a situation or a chain of intermediate endogenous forms, up to the final one, can have methodological value;

- the final endogenous ontological model of the situation can be of great importance, since, according to the scenario of solving the problem, it must have some of the sought-after characteristics of the problematic situation.

Note that the meta models under construction - meta-ontologies and ontologies of problem solvers - define a unified representation for both themselves and all the results of individual stages of the ontological modeling scheme (Fig. 1).

Thus, ontological modeling, forming a multi-model environment, ensures uniformity of all without the exclusion of the models created in the process of making a decision on the regulation (overcoming) of a problem situation.

In the figure. 1 of the scheme, it is assumed that the decision to resolve the problem situation is carried out as a result of the consensus of the entities reached through negotiations to bring their positions closer.

This means that if the built ontological model of the situation does not suit at least one of the subjects, then the decision is not made, and in the final stage of decision making, one returns to any of the previous stages.

Such iterations can be repeated several times, which will lead to a delay in the decision-making time, and in order for them not to go beyond the permissible limits, it is necessary to constantly monitor the state of development of the situation.

If the subjects understand that the time for making a decision will soon end, this will encourage them to make mutual concessions to find compromises In other words, the number of iterations needed to reach consensus will self-regulate, providing real-time control.

With this approach to decision making, a bet is made on the solidarity of the subjects.

An alternative is the "majority principle»: do not waste time on lengthy negotiations and rapprochement of positions, but make a decision by a simple majority of votes.

In this case, time can actually be saved, but there are no guarantees of the quality of the solution, since some of the entities that have significant arguments do not agree with the chosen method of resolving the problem situation.

Therefore, voting, which does not involve joint negotiations and mutual understanding, cannot be recognized as an acceptable way of decision-making in situational management, focused on the effective use of intellectual and volitional resources of all entities involved in resolving a problem situation.

Final Results and Conclusions. In organizing decision-making processes in poorly formalized complex systems, ontological models play a key role: formal descriptions of conceptual structures; persons involved in decision-making (subjects), ontologies and 
object descriptions of problem situations within the framework of such conceptual representations (ontological models of the situation).

The developed methods for the unification of ontological models allow one to take into account the diversity of the knowledge involved and the variety of mechanisms of their use, and the corresponding information systems open up new possibilities for solving the multidisciplinary tasks of situational management in social and technical systems.

The article analyzes the similarities of the structural diagram of the decision-making process for regulating the problem situation and the general scheme of ontological modeling.

Between the elements of these schemes, compliance is established to justify the ontological approach to the implementation of situational management.

The contents of the corresponding elements of the schemes are compared with the aim of revealing the mechanisms of situational management.

The construction of information models of understanding in situational management is proposed to be considered as the task of constructing ontologies of subject areas and ontological models of situations.

\section{REFERENCES}

Kulinich, A.A., 2003. Metodologiia kognitivnogo modelirovaniia slozhnykh plokho opredelennykh situatcii [The methodology of cognitive modeling of complex poorly defined situations]. In: Vtoraia mezhdunarodnaia konferentciia po problemam upravleniia [Second International Conference on Management]. Moscow. Russia, June 17-19, 2003. Moscow: IPU RAS, pp.219226. [online] Available at: <http://www.raai.org/about/persons/kulinich/> [Accessed 31 March 2020].

Maksimov, V.I., Kornoushenko, E.K. and Kachaev, S.V., 1999. Kognitivnye tekhnologii dlia podderzhki priniatiia upravlencheskikh reshenii [Cognitive technologies to support managerial decision making]. Informatcionnoe obshchestvo, [online] 2, pp.50-54. Available at: <http:// emag.iis.ru/arc/infosoc/emag.nsf/BPA/092aa276c601a997 c32568c0003ab839> [Accessed 31 March 2020].

Kostenko, K.I., 2016. Modelirovanie operatora vyvoda dlia ierarkhicheskikh formalizmov znanii [Modeling the inference operator for hierarchical knowledge formalisms]. Programmnaia inzheneriia, 9 (7), pp.424-431.

Denisenko, V.N. and Krasina, E.A., 2014. Obshchaia teoriia sistem i lingvisticheskaia sistemologiia professora G.P. Melnikov: Metodologiia i metodika [General Theory of Systems and Linguistic Systemology of Professor G.P. Melnikov: Methodology and methodology]. Vestnik Rossiiskogo universiteta druzhby narodov. Seriia Teoriia iazyka. Semiotika. Semantika, 1, pp.15-21.

Tablichnye informatcionnye modeli - Avtor24 [Tabular Information Models - Posted by 24]. [online] Available at: <https://spravochnick.ru/ informatika/ informacionnaya_ model/tablichnye_informacionnye_modeli/> [Accessed 28 March 2020].

Chto takoe reliatcionnaia baza dannykh i SUBD [What is a relational database and DBMS]. Laboratoriia linuksoida [online] Available at: <https://younglinux.info/sqlite/db $>$ [Accessed 21 April 2020]. 
Rubakov, S.V., 2008. Sovremennye metody analiza dannykh [Modern methods of data analysis]. Upravlenie naukoi i naukometriia, [online] 7. Available at: <http://riep.ru/upload/ iblock/031/031173bb40e099800b248497db44cb88.pdf> [Accessed 30 April 2020].

Tkachenko, O., Tkachenko, A., Ovcharuk, I., Tkachenko, K., Radionov, B. and Chyhyr, I., 2019. Modeling of process management in online lending. Norwegian Journal of development of the International Science, 35 (1), pp.44-49.

Greger, S.E. and Porshnev, S.V., 2013. Postroenie ontologii arkhitektury informatcionnykh sistem [Building an ontology of information systems architecture]. Fundamentalnye issledovaniia, 10, pp.2405-2409.

Intellektualnye kompiuternye tekhnologii podderzhki priniatiia reshenii [Intelligent computer technology decision support]. [online] Available at: <http://www.ipu.ru/labs/lab51/projects. htm> [Accessed 25 April 2020].

Smirnov, S.V., 2001. Ontologicheskii analiz predmetnykh oblastei modelirovaniia [Ontological analysis of subject areas of modeling. Bulletin of the Samara Scientific Center of the Russian Academy of Sciences]. Izvestiia Samarskogo nauchnogo tcentra Rosiiskoi akademii nauk, [online] 3 (1). Available at: <https://cyberleninka.ru/article/n/ontologicheskiy-analiz-predmetnyh-oblastey-modelirovaniya> [Accessed 25 April 2020].

Bondarenko, M.F., Matorin, S.I. and Soloveva, E.A., 2000. Osobennosti teorii i praktiki resheniia slozhnykh zadach na osnove ontologii [Features of the theory and practice of solving complex problems based on ontology]. Iskusstvennyi intellekt, 3, pp.25-33.

Osipov, G.S. Dinamicheskie modeli i instrumenty s ispolzovaniem empiricheskikh i ekspertnykh znanii [Dynamic models and tools using empirical and expert knowledge]. [online] Available at: <http://www.raai.org/about/persons/osipov/pages/dokl_osipov.html> [Accessed 25 April 2020].

Boev, V.D. Mnogoagentnye sistemy [Multi-agent systems]. [online] Available at: <https://studme.org/163996/informatika/multiagentnye_sistemy> [Accessed 25 April 2020]. 


\section{Удк 004.02:005}

\section{Ткаченко Ольга,}

кандидат фрізико-математичних наук,

доцент кафедри інформаційних технологій,

Державний університет інфраструктури та технологій,

Київ, Україна

oitkachen@gmail.com

https://orcid.org/0000-0003-1800-618X

\section{Ткаченко Олександр,}

кандидат фізико-математичних наук,

доцент каредри інженерії програмного забезпечення,

Національний авіаційний університет,

Київ, Україна

aatokg@gmail.com

https://orcid.org/0000-0001-6911-2770

\section{Ткаченко Костянтин,}

кандидат економічних наук,

старший викладач кафедри інформаційних технологій,

Державний університет інфраструктури та технологій,

Київ, Україна

tkachenko.kostyantyn@gmail.com

https://orcid.org/0000-0003-0549-3396

\section{ОНТОЛОГІЧНЕ МОДЕЛЮВАННЯ СИТУАЦІЙНОГО УПРАВЛІННЯ}

Мета статті - дослідити та розглянути загальні проблеми та перспективи моделювання ситуаційного управління, зокрема онтологічного моделювання.

Методи дослідження - це методи семантичного аналізу основних понять розглянутої предметної сфери (ситуаційний менеджмент). У статті досліджено підходи до розробки відповідних онтологічних моделей.

Новизна дослідження - аналіз онтологій та їх застосування в моделюванні процесів ситуаційного управління.

Висновки. У статті проаналізовано схожість структурної схеми процесу прийняття рішень щодо регулювання проблемної ситуації та загальної схеми онтологічного моделювання. Між елементами цих схем встановлюється відповідність для обгрунтування онтологічного підходу до реалізації ситуаційного управління. Зміст відповідних елементів схем порівнюють з метою розкриття механізмів ситуаційного управління. Побудову інформаційних моделей розуміння ситуаційного управління пропонують розглядати як завдання побудови онтологій предметних сфер та онтологічних моделей ситуацій.

Ключові слова: предметна сфера; системні моделі; онтологія; модель онтології; ситуаційне управління; процес прийняття рішень; регулювання проблемної ситуації. 


\section{УДК 004.02:005}

\section{Ткаченко Ольга,}

кандидат фризико-математических наук,

доцент кафедры информационных технологий,

Государственный университет инфраструктуры и технологий,

Киев, Украина

oitkachen@gmail.com

https://orcid.org/0000-0003-1800-618X

\section{Ткаченко Александр,}

кандидат физико-математических наук,

доцент каредры инженерии программного обеспечения,

Национальный авиационный университет,

Киев, Украина

aatokg@gmail.com

https://orcid.org/0000-0001-6911-2770

\section{Ткаченко Константин,}

кандидат экономических наук,

старший преподаватель кафедры информационных технологий,

Государственный университет инфраструктуры и технологий,

Киев, Украина

tkachenko.kostyantyn@gmail.com

https://orcid.org/0000-0003-0549-3396

\section{ОНТОЛОГИЧЕСКОЕ МОДЕЛИРОВАНИЕ СИТУАЦИОННОГО УПРАВЛЕНИЯ}

Цель статьи - исследовать и рассмотреть общие проблемы и перспективы моделирования ситуационного управления, в частности онтологического моделирования.

Методы исследования - это методы семантического анализа основных понятий рассматриваемой предметной области (ситуационный менеджмент). В статье рассматриваются подходы к разработке соответствующих онтологических моделей.

Новизна исследования - анализ онтологий и их применение в моделировании процессов ситуационного управления.

Выводы. В статье проанализировано сходство структурной схемы процесса принятия решений по регулированию проблемной ситуации и общей схемы онтологического моделирования. Между элементами этих схем устанавливается соответствие для обоснования онтологического подхода к реализации ситуационного управления. Содержание соответствующих элементов схем сравнивается с целью раскрытия механизмов ситуационного управления. Построение информационных моделей понимания ситуационного управления предлагается рассматривать как задачу построения онтологий предметных областей и онтологических моделей ситуаций.

Ключевые слова: предметная область; системные модели; онтология; модель онтологии; ситуационное управление; процесс принятия решений; регулирование проблемной ситуации.

24.04.2020 